\title{
An Analysis of Self-mockery in Conversational Implicature
}

\author{
Wen Minlin \& Chen Yali \\ School of Foreign Languages, China West Normal University \\ Nanchong, Sichuan province, China, 637002 \\ 38092990@qq.com \\ 252863009@qq.com
}

Keywords:Self-mockery; conversational implicature; cooperative principle

Abstract:Self-mockery, as an indispensable communicative device, has been playing an important role in our life. It can adjust intense atmosphere in communication, alleviate mental pressure and amend participants' relationship。Self-mockery, mocks oneself apparently, but in fact it is not. Because, it is on the one hand, taken as a irony, on the other hand, as a kind of humor.

Up to now, all of these researches in China about self-mockery conversations are conducted from the perspective of social communication and literacy appreciation which focus on the analysis of the commemorative functions and the implied self-mockery consciousness and the attitude of the author in the literary works. but they are confined to the social communication part and neglect the interpretation mechanism of self-mockery and its implicature in conversation.Under the framework of pragmatics, this paper aims to analysis the pragmatic elements and the conversational implicature in order to open a new road for self-mockery research.

\section{Introduction}

Self-mockery means make fun of oneself or self-teasing. In a broader range,self-mockery is a kind of banter; in a narrow range,it belongs to self-teasing,and the objects of self-mockery are just confined to oneself or things concerned. It can adjust intense atmosphere in communication, alleviate mental pressure and amend participants' relationship。It is on the one hand, taken as a irony, on the other hand, as a kind of humor. Maynard (1996) who firstly uses the term(self-) parody to refer to the phenomenon of self-mockery [1]; Satoka Suzuki (2001)defines self-mockery as a linguistic act in which the speaker makes a statement and then denies, or expresses his/her 
non-serious attitude toward the content of the utterance [2]; For Attardo (2002), self-mockery discourse generally contains the literal meaning and the implied meanings, both of which are a kind of indirect deny relationship [3].Leech have also made a lot of analyses about the inconsistent meaning behind self-mockery $[4,5]$.

Although a lot of progress has already been made in the study of self-mockery, some of them are not very pragmatically profound. These researches contribute to the study of self-mockery conversation and its value in emotional expression in the perspective of social communication and literary appreciation,but they are confined to the social communication part and neglect the interpretation mechanism of self-mockery and its implicature in conversation. Under the framework of pragmatics, this essay aims to apply cooperative principle proposed by Grice [6] and politeness principle to make an analysis of pragmatic essence of self-mockery. It pays more attention to the pragmatic elements and the conversational implicature in order to open a new road for self-mockery research, try to figure out how the self-mockery conversation organized and what the real purpose of the speaker in self-mockery conversation is, that is to say we should analyze why the speaker fail to observe the maxim of cooperative principle to reveal the conversational implicature behind it.

Meanwhile, from the perspective of the speaker's intention, Grice divides meaning into natural meaning and non-natural meaning [7]. Their main distinction is whether speaker's intentions or conventions are contained in the utterance. The method, which studies meaning through speaker's intentions, has laid foundation for Theory of Conversational Implicature. When the speaker deliberately violates the maxim of Cooperative Principle to demonstrate his intentions, Conversational Implicature will arise from the utterance. Conversational Implicature is what listeners infer from the speaker's intention, together with context, background knowledge and the Cooperative Principle.

\section{Factors Influencing the Effect of Self-mockery}

Self-mockery can be used elastically, but the following key factors should be noticed during the processing of self-mockery interpretation.

\section{Context}

Context is a relationship between language unit and the adjacent discourse, as well as non-linguistic factors. Context the thinking background for self-mockery in a conversation. 
Self-mockery as a communication strategy, its essence is to make communication activities produce objectification, situation effect in particular cognitive context, whose relationship to the context is the inappropriateness of proposition.For example:

(1) Charlie should leave the everyday.

(2) Charlie is in the everyday.

(1) Presume (2), if (2) is false,(1) becomes inappropriate.The inappropriateness of self-mockery proposition reflects different degree variable through conventional relationship triggering the psychological expectation in reference context. This means that self-mockery selects subject content or field, which is always distinct from psychological expectation,presenting different codes,forms and styles, or a kind of abnormal coding procedure, to make the discourse contradict with logical development order of things.

\section{Intention}

Self-mockery in communication is a process to make an inference from the communicative intention of the speaker. The production and comprehension of such kind discourse needs participates' cognition. The activation of the communicators' affection schema or framework is the key to understand self-mockery conversation. It is obviously that adjusting the original framework appropriately is an irreplaceable process, which would guarantee a successful communication. To make a self-mockery communication to be comprehended, the pragmatic inference with the cooperative principle or the conversational implicature should be considered. Once we find the implied meaning between the speaker and the hearer, we can have s deeper understanding and get the intention of the speaker.

\section{Nonverbal Communication Factors}

Self-mockery in communication not only considered as an important communicative tool, but also has many nonverbal communication factors such gesture, facial expressions and eye contact. A gesture is a form of non-verbal communication made with a part of the body, instead of verbal communication. Gesture may replace speech,regulate the flow and rhythm of interaction,maintain attention,add emphasis and clarity to speech,help characterize and make memorable the content of speech and act as forecasters of forthcoming speech.

Facial expression is anther nonverbal language to express one's emotion, to show interpersonal attitudes, to provide nonverbal feedback on the comments of others.In the process of 
communication,racial expression serves as the most important cues for the recipient to make judgment. It can also enhance the effects of self-mockery in communication activity.

\section{Conversational Implicature of Self-mockery under Different Pragmatic Purposes}

Self-mockery can help the speaker get out of the embarrassing situation and adjust personal relationship with harmonious atmosphere. Attardo once pointed out that, "Humor is derived from a sudden change from expectation to expectation failure" [8]. Norrick uses frame theory to describe the humor, and points out that "joke firstly activate a schema, then distorted it [9]." During daily life, conflict and friction among people is ubiquitous in everywhere. Self-mockery can help you get a win-win situation, stop conflicts to upgrade, resolve the conflicts, and even reveal your personality of magnanimous mind and noble style.

Self-mockery seems intentionally fail to observe the maxim within the cooperative principle, and it give rise to the conversational implicature because of self-mockery in conversations. In the following text, we may illustrate the conversational implicature under different purposes by elaborate different examples about self-mockery conversations.

\section{Self-mockery for Complaint}

The Greek philosopher Socratic's wife is a shrew, who often lost her temper. And our philosopher usually say "marrying such a wife, I can benefits a lot such as exercise endurance, deepen my culture". Once, the wife hit the ceiling by kicking up a fuss. She has been wrangling for a long time, Socrates had to wince. When he just walked out of the door, the still angry wife suddenly dump big basin water from the upstairs, making him soaked like a drowned rat. Facing the onlookers of neighbors. Socrates smiled, "I already know, there will be a heavy rain after loud thunder, just what I thought."

We should notice that here by saying "marrying such a wife, I can benefits a lot such as exercise endurance, deepen my culture". Socrates obviously broke the maxim of quality of cooperative principle (do not say what you believe is false). Because he can't deepen his culture because of his wife's bad temper. He just wants to avoid awkward. And "I already know, there will be a heavy rain after loud thunder, just what I thought." is also flouting the maxim of relevance. But the apparent irrelevance is actually a metaphor, which means that his wife's bad temper is mapped to a loud thunder. Through this self-mockery, Socrates successfully avoided the embarrassment 
showed his charming personality. Therefore he actually used self-mockery to complain his wife' deed.

\section{Self-mockery for Counterattack}

Self-mockery as a weapon can protect them from viciously attack, even counterattack others. Here is an example:

During 1932,Franklin Roosevelt as the democratic presidential candidate joined in the race of presidential election. The Political opponents file commonly used his disability to attack him. Once when he is in the debate with his rival, the other side found fault with his body's defect and said how a disabled people call govern the country well.Roosevelt said wryly in low profile, "alas! So, you're right, my body has a defect, I can't do forward tumble or backward tumble." And then he immediately changed topic: "a President is not necessarily all acrobats, what he did is mental labor, who is trying to benefit for the people." His humor answer drew the burst of applause from the audience.

Facing the opponent's personal attack, Roosevelt didn't debate with his opponent just as people expected, but just saying "I can't do forward tumble or backward tumble" this is actually a very strange answer, why should he brother to mention forward tumble and backward tumble if he just want to confess that he was disable. This answer, according to cooperative principle, violates the maxim of manner (be brief, avoid unnecessary prolixity). But at a deeper thinking, we can understand that Mr. Roosevelt just used self-mockery as a weapon to counterattack his opponent's insult but in a humorous not a fierce way. It is no wonder that in the end he became the 32 nd American President, also the only four times President in the history of the United States.

\section{Self-mockery for Modesty}

Self-mockery can also become a way to express one's modesty by somehow teasing himself, which also make an easier atmosphere among people.

Former president Bush once addressed a speech in the graduation ceremony of Yale University, and he successfully used self-mockery to express his modesty. During this speech, he frankly classified himself into "the level of C students", when he was in praise of those outstanding students who got various rewards. He said frankly that the students who got $\mathrm{C}$ also call succeed, even can be President of the United States.President Bush's modesty make the speech a great success.

We know that maybe president used to get $\mathrm{C}$ in the university, but he can't be the $\mathrm{C}$ level 
student as an honored alumnus from Yale University. So why did he lie? And why did he flout the Maxim of Quality of Cooperative Principle (do not say what you believe to be false)? we must confirm that Bush is trying to be cooperative, so what he said is informative. So we can assume that what he said is just self-mockery, and he was just want to show his modest to encourage students that even if they get $\mathrm{C}$ in university, they can still be successful in the future.

\section{Self-mockery for Apology}

In interpersonal communication, it is hard to avoid mistakes or impoliteness. Say if you did something impolite to others, self-mockery would be a appropriate way to apologize,it wouldn't lose your face and is easy to let others to accept you apology. If accidentally stepped on the feet of strangers, you can immediately mock yourself by saying how stupid you are. It not only expresses your regret, but also call set aside a space for the other party to forgive you.This device of course violates the principle of quality apparently. But the hearer can get the inference that it is an apology actually. For example:

A:Oh, what a stupid foot which trod on your toe!

B:Never mind. It doesn't really matter.

To make the apology successful, we should understand the conversational implicature behind it. From what A say "Oh, what a stupid foot which trod on your toe!", we know that A actually violate the cooperative principle(maxim of quality).Because a toe is not a human, and is can never be described as stupid. B however can understand the conversational implicature that A is trying to use self-mocker as an apology.

\section{Self-mockery for Decline}

Due to the external causes or internal motivation such as unwilling,dislike.one has to reject something or people. Too direct rejection is against the politeness principle in communication,but self-mockery can provide a polite way of refusing.

Once a friend in the press who is on good terms with Lincoln invited he to give a speech in the editor conference. Lincoln didn't work as editor before and knew nothing about edictal work. But it is not good to directly refuse friends, so Lincoln told a story to his friend: "one time, I walked in the forest and came across a woman who riding a horse.I stopped to get out of the way, and she also stopped and stared at me.She said: 'I believe that you are the ugliest man that I've ever seen.' I said: 'you are probably right, but what could I do?' she said, 'yes, you can't change your grimace, but 
you can stay at home!' The friend can't help laughing for Lincoln's humorous self-mockery, at the same time, he understood Lincoln's meaning and gave up his thought.

Lincoln achieve his purpose by violate maxim of quality (then woman had no evidence that he was the ugliest man in the word) and maxim of quantity(he didn't make his words as informative as he can). Lincoln's friend can make the inference and understand why he broke the cooperative principle.

\section{Self-mockery for Remorse}

Self-mocker can be a good way of expressing self-accusation and remorse for one's own fault.

Though the well-known millionaire, Rockefeller gave away millions, he was very mean about a small slim of money. One day, he went to stay at a hotel in New York and asked for the cheapest room. The manager said: "That is the smallest and the cheapest we have," and add "but why do you choose a poor room like that? When your son stays here, he always has our most expensive room, while yours is our cheapest." "Yes," said Rockefeller, "But his father is a wealthy man while mine isn't."

Here we can see he violates the maxim of quantity, because he didn't make his contribution as informative as he is required. The words about his father and his son's father are complex. Although by breaking the cooperative principle he can not only solve the manager's confusion, on the other hand embodies a kind of deep remorse:the son don't understand the tough of life, partly because his father has much money to let him lead a luxury luxurious life. He is regretted that he doesn't teach his son well.

\section{Self-mockery for Covering up Embarrassment}

In 1941, Winston Churchill assumed office as the prime minister soon, he personally came to America to meet with President Roosevelt in order to understand the U.S.foreign policy.In the morning early of the second day after Churchill arrived the U.S,Franklin Roosevelt came to visit the guest Churchill who live in the White House.It just happens to see Churchill get out of the shower, who was naked and just walking out of the bathroom. Roosevelt felt very embarrassed, and was ready to immediately turn away.At that moment, Churchill said to him with all easy grace: "The Prime minister of Britain has nothing to conceal from The President of The United States."(You see! The British Prime minister is very flank to The President of The United States, there is not secret at all") In fact, it is a shameful thing to let others see you are naked, but Churchill dissolved the 
embarrassment by self-mockery, meanwhile, expressing the respect and sincerity of the British people toward the American people.

At the sight, we may think Churchill violates the maxim of reverence, because it seems that there is no relation between Churchill is naked and his is frank to the US. But at a deeper thought, we can understand Churchill is trying to use his uncover as his frank attitude to America.

\section{Self- mockery for Relief}

Facing the social inequality, the gulf between the rich and the poor as well as ups and downs in life, many people often complain all day or envy others, and even desperate themselves, but some make fun of life to console.

After retirement, Bush stayed at home,sometimes had a walk with his dog in the park for killing time. He often carry a plastic bag behind his dog and was ready to pick up the feces out of the dog.Some people say, "this is the President of the United States, who also had to be the attendant of a little dog". Bush said wryly, "after leaving office, my wife Laura asked me to do housework, so now washing dishes become my new internal affairs. When I am idle, I took my dog for a walk with a plastic bag for the dog's rehabilitation work. Hearing this words, the gathered people didn't say anything, but admire Bush's broad heart. Although he was ever the President, at home he also is a model husband and a "henpecked".

Bush also violates some cooperative principle in order to do the self mockery, but the conversational implicature help he successfully achieve his purpose.

From all those different purposes of self-mockery, we can analyze their pragmatic meaning, that is the cooperative principle and conversational implicature we can get from the self-mockery conversations.

\section{Conclusion}

In a traditional scale, self-mockery belongs to the category of interpersonal rhetoric with of great theoretical significance and practical effect, the researches about self-mockery discourse are mostly conducted from the perspective of social communication and literacy appreciation which focus on the analysis of the commemorative functions and the implied self-mockery consciousness and the attitude of the author in the literary works.But in this paper, self-mockery has a variety of pragmatic characteristics, Therefore, the theoretical research on self-mockery can expand the range 
of pragmatics especially how the cooperative principle used and the conversational implicature behind it.

In the application layer, self-mockery can achieve many purposes such as: for relief, for apology, for covering up embarrassment, for modesty, for complain, for counterattack, for remorse, and for decline. By using self-mockery people can make a relaxed and harmonious atmosphere for talking,make life free and easy, promote one's personality charm,maintain face more effectively and can establish a new psychological balance. That is why self- mockery is a communicative skill. But, the most important is to understand self- mockery is a pragmatic way.

\section{References}

[1]Maynard,Senko K.Mulfivoicedness in speech and thought representation:the case of self-quotation in Japanese[J].Journal of Pragmatics,1996, 207-226.

[2]Satoko Susuki. Self-mockery in Japanese [J] Lingustics , 2002.

[3]Attardo,Salvatore. kony as Relevant Inappropriateness[J].Journal of Pragmatics, 2000,(32):793-826.

[4]Leech,G.Principles of Pragmatics[M].Longman,London,1983.

[5]Leech,G.Principles of Pragmatics[M].London:Longman Group Ltd.1983

[6]Grice, H. P. Meaning[J]. The philosophical review, 1957, 66:377-388.

[7]Grice, H.P. (1989). Studies in the Way of Words. Harvard University Press.

[8]Attardo,Salvatore.The semantic foundations of cognitive theories of humor.Humor:International Journal of Humor Research, 1997,(10-4):396.

[9]Norrick, N.R.A frame-theoretical analysis of verbal humor:bisociation as schema conflict[J]. Semeotica 60(1986):255-245. 